\title{
Prospects for growth and issues in marketing of health insurance in India
}

\author{
Manoj Pareek \\ Assistant Professor, Manipal Academy of Higher Education (Deemed University), Bangalore Campus, Research Scholar, \\ Tumkur University, Tumkur, Karnataka, India \\ *Corresponding Author: \\ Email: manoj.pareek@manipal.edu
}

\begin{abstract}
Health insurance market in India has become the fastest growing segment in non -life insurance sector in India. The health insurance business in India saw a 24\% growth in FY 17 with a premium of INR 30,765 Cr and a market share of 24\%. It has been the fastest growing market segment registering a CAGR of $23 \%$ for the past 10 years. Health insurance industry is in a nascent stage with $25 \%$ of population under its coverage. There exists a huge potential for growth and penetration of health insurance to a large population. Going forward there are both opportunities and obstacles in marketing and distribution of health insurance products in India. This paper attempts to uncover the prospects of successful marketing of such products from the standpoint of insurance marketers and look at issues of impeding the growth of health insurance market in India.
\end{abstract}

Keywords: Challenges, Drivers, General insurance, Health insurance, Opportunities, India.

\section{Introduction}

Health insurance is a part of general insurance sector. Indian non-life insurance industry continues to be underpenetrated when compared globally. Insurance penetration is in range of $0.5-0.8 \%$ for the past 10 years. It was 0.77 in year 2016. Insurance density grew from $\$$ 2.4 in 2001 to $\$ 13.2$ in 2016 . This shows that there is huge potential for growth. With health insurance being the second largest, segment of non-life insurance industry. India has been experiencing high growth in private health insurance over past 10 years. This high growth has happened due to a numbers of factors or growth drivers. Industry also faces issues, which impede the growth in this sector.

Before we embark to understand the prospects for growth and constraints affecting the growth of health insurance in India. We need to delve into delivery, consumption and financing of healthcare in India. We would touch upon delivery mechanisms and consumption later; to start with let us look at financing mechanisms for providing healthcare by Indian government to its citizens.

There are four major suppliers for financing healthcare as enumerated in Table 1.

Table 1: Sources of healthcare financing: Indian scenario

\begin{tabular}{|l|c|}
\hline \multicolumn{1}{|c|}{ Sources of Healthcare Finance } & Indian Scenario \\
\hline Direct Taxes on Income for Insurance & Does not exist \\
\hline Social Health Insurance Schemes by Govt. & Employee State Insurance Scheme (ESIC) \\
& (Starting Year1952) \\
& Central Government Health Scheme (CGHS) \\
& (Starting Year 1954) \\
& Schemes by State Government \\
& Central Government Schemes : \\
& Rashtriya Swasthya Bima Yojana (RSBY) \\
& (Starting Year 2008) \\
& Ayushmaan Bharat Yojna -National Health Protection \\
& Mission (Year 2018-2019) (Proposed) \\
\hline Private Health Insurance or Voluntary Insurance & $\begin{array}{c}\text { Started in 1986 with Mediclaim by 4 Public Sector } \\
\text { companies. Now All General Insurers and Stand Alone } \\
\text { Health Insurance Companies offering the same }\end{array}$ \\
\hline $\begin{array}{l}\text { Out of Pocket Spends or Self-financing by } \\
\text { Citizens }\end{array}$ & Nearly 70\% borne by citizens themselves \\
\hline
\end{tabular}

In Indian context where majority of population is self-employed, a tax based system or payment by employers is not feasible. Further, ESIC and CGHS scheme leave self-employed people out of its purview. State run schemes and RSBY (Rashtriya Swasthya Bima Yojana) the first national scheme aiming at universal coverage have not made any dent because of low quantum of cover of INR 30000 and narrow scope of coverage.

Public spending on health in India (centre and state governments put together) has been in the range of 1.01- 1.3\% of the GDP between 2008 and 2015, 
and was $1.4 \%$ in $2016-17$ against the average of $6 \%$. globally. The national health policy 2017 aims to "increase health expenditure by government as a percentage of GDP from the existing $1.15 \%$ to $2.5 \%$ by 2025". Out of pocket expenses, mean expenses where a patient pays for his medical expenditure on his own. Out of the total expenditure done by citizens themselves in India is nearly $70 \%$, which is very high in comparison with countries world over. Private expenditure as a share total health care expenditure of $4 \%$ of GDP is around $70 \%$ and public spending by government is mere 30\%. In South East Asia, all countries were better off than India in this regard except Pakistan.

During 2016-17, general and health insurers settled 1.10 crore health insurance claims and have paid Rs. 27546 crore towards health insurance claims. Private voluntary health insurance funded health expenditure of approximately $5 \%$. Health financing mechanisms should ensure affordable healthcare is available to the fortunate and not so fortunate poor citizens.

Health insurance forms a significant part of health financing globally. Whether is comes through government run schemes or private health insurance the aim being healthcare being accessible to all. In India where $70 \%$ out of pocket expenses are paid by its citizens. High growth is being seen in each form of health insurance and will continue to exhibit the same in future.

\section{Drivers of Growth of Health Insurance Market Current Population and Demographics}

Population that stood at 1.35 billion at end of FY 18 is expected to grow by 1.4 billion by 2026 giving rise to demand for healthcare services and health insurance in India. India is currently the second most populous country in the world and is currently growing at a rate of $1.4 \%$ per year.

India is young nation in 2011 as per census, $58.3 \%$ of the population was less than 30 years and $17.6 \%$ was between $20-29$ years. Over $31 \%$ of the population was urban. Nearly $42 \%$ of the urban population was $20-44$ years. This provides a huge market of young earners who can buy insurance for themselves and their dependents.

\section{Increase in Disposable Incomes}

Investors see India as one of the key markets from where future growth is likely to come. The growth in India's consumer market would be driven by a favourable population composition and increasing disposable incomes.

Indian per capita income has been growing steadily. It is estimated that per capita GDP of India will be US\$ $3,273.85$ in 2023 from US\$ 1,983 in 2012. The macroeconomic indicators for India's growth are good. More disposable income in hands of citizens means the ability to buy financial services goes up. Indian insurance market is generally divided into urban and rural markets, and is attracting investments from across the world. The sector comprises of a huge middle class, relatively large affluent class and a small economically disadvantaged class, with spending anticipated to double by 2025 .

\section{Rise in Prevalence of Lifestyle Related Diseases}

The pattern and trend of ailments and diseases in India are now showing resemblance to western countries. Indians were inflicted with communicable diseases like malaria, hepatitis, jaundice, typhoid, tuberculosis, influenza etc. earlier mainly due to lack of hygiene, poor sanitation standards, contaminated water. These typical diseases affected people of developing countries. With rise in prosperity of a certain section of society, rapid urbanization, pollution, physical inactivity increasing use of tobacco and alcohol, changing food habits has led to arrival of non-communicable diseases in India. These are heart diseases, asthma, diabetes, cancer and hypertension. There are over 60 million type 2 diabetes sufferers in India, the largest in any country. Some are calling India the diabetes capital of the world. These diseases by definition last a lifetime and therefore are a huge strain economically. These diseases do not cause death immediately but require medical expenses to be incurred for treatment for a long period. Health insurance is now being taken a large population who feel a need to buy the same considering the increasing prevalence of such diseases in society around them.

\section{High Medical Inflation}

India has general inflation of about 6-7 percent, and in field of healthcare is as high as 15 percent. A high medical inflation of around 15 percent per year is making the healthcare beyond the reach of many. The costs of medical care are rapidly rising. The cost of surgeries, doctors' fees, room rent; medical devices are increasing every year. Since an average household cannot lay access to high sums with ease, people have to liquidate savings or borrow from family and financial institutions to cover their medical expenses. A large segment of population is now aware of the high costs of healthcare and is being driven to health insurance due to the same.

\section{Digitalisation of Health Insurance}

India is the second largest online market with 460 million internet users. Estimated to grow to 635.8 million by year 2021. It became the third largest smartphone market in 2017 with smartphone shipments growing 14 per cent y-o-y to 124 million.

Internet permits growth of the health insurance industry. A recent survey conducted by FICCI-(The Federation of Indian Chambers of Commerce and Industry) showed online sales will grow 15-20 times by 2020 for the sector. Insurers have made retail health products available on their own websites, apps and other online platforms making it handy for customers to buy 
the policies directly. Web Aggregators (comparison websites) a distribution channel becoming popular among youth. This again is leading to growth in online sales of retail health

\section{Increase in tax Exemptions on buying of Health Insurance}

People in India still look at tax benefits for insurance premium payments and this is an effective stimulus towards increasing the penetration of health insurance. These have been increasing year on year.

The maximum amount on which tax deduction can be claimed has increased to Rs 1 lakh for the financial year (FY) 2018-19 from the previous Rs 60,000 for FY 2017-18. See Table 2 below for current benefits for FY 2018-2019.

Table 2: Tax benefits on payment of premium

\begin{tabular}{|l|c|c|c|c|}
\hline S. No. & Income Tax -Section 80-D Benefits & Financial year - 2018-19 & & $\begin{array}{c}\text { Total } \\
\text { Exemption }\end{array}$ \\
\hline & Situation & $\begin{array}{c}\text { Deduction Limits on } \\
\text { Payment of Premium }\end{array}$ & (In Rs.) \\
\hline 1 & Members < 60 years & Self/Spouse/Children & Parents & Rs. 50000 \\
\hline 2 & Eldest Members < 60 years & Rs. 25000 & Rs. 25000 & \\
\hline & Parents any one $>60$ years & Rs. 25000 & Rs. 50000 & Rs. 75000 \\
\hline 3 & Eldest Member $>60$ years & & & \\
\hline
\end{tabular}

Measures Taken by IRDAI (Insurance Regulatory and Development Authority of India) to increase Investments: Insurance industry as well as health insurance is capital intensive. It requires huge investment by insurers of capital and has a long gestation period. IRDAI the regulator took the following steps to increase flows of capital

Raising of Foreign Partners Stake in Indian Insurers from $26 \%$ to $49 \%$ : Indian insurance act was amended to allow Foreign Direct Investment that was capped at $26 \%$ to $49 \%$. Since then many foreign partners have increased their stakes in Indian Insurers bringing in much needed additional capital

Investment allowed by Private Equity Investors in Insurance Sector: Private equity investors were permitted by IRDAI to act promoters in unlisted Indian Insurers.

Allowing Raising of Capital by Listing on Indian Stock Exchanges: IRDAI's move to relax capital raising norms last August, 2016 (by allowing insurance companies over 10 years to go public), has pushed many companies to tap Indian capital markets. The listed Insurers post 2016 guidelines are

Life Insurers

HDFC Standard Life Insurance Co. Ltd

SBI Life Insurance Co. Ltd
ICICI Prudential Life Insurance Co. Ltd

\section{General Insurers}

ICICI Lombard General Insurance Co. Ltd

The New India Assurance Co. Ltd

General Insurance Corporation of India (Reinsurer)

Opening up of Bancassurance Market by allowing Banks to have Multi Insurer Tie ups: In India banks, operated as corporate agents for an insurer as per IRDA (Licensing of Corporate Agents) Regulations 2002. The Corporate Agent regulations were amended in August 2015 and new regulations came into effect from 1 April 2016. From April 1, 2016, rules were amended to allow banks to tie-up with 3-life, 3 non-life and 3standalone health Insurers. Prior to this change in rules banks could only distribute products of one life, one non-life and one standalone health insurer. Banc assurance as a channel is the fastest growing channel in India. This opens the market for insurers to increase business by tapping in huge base of banks customers spread across vast geographies. Now insurers can have more bank partners than before and leverage this to their advantage.

Rise of Standalone Health Insurers: Standalone health insurance companies were created by IRDA in 2006 to focus on health insurance, personal accident and travel insurance products.

Table 3: Gross direct premium income -(2017-18)

\begin{tabular}{|l|c|c|c|c|}
\hline Standalone Pvt Health Insurers & Premium 2017-2018 (In Rs. Cr) & \multirow{2}{*}{ Market Share 2017-18 } & \multirow{2}{*}{ Growth\% } \\
\cline { 1 - 3 } Company Name & $\mathbf{2 0 1 7 - 1 8}$ & $\mathbf{2 0 1 6 - 1 7}$ & & \\
\hline Apollo MUNICH & $1,717.50$ & $1,301.93$ & 1.14 & 31.92 \\
\hline Cigna TTK & 346.41 & 221.8 & 0.23 & 56.18 \\
\hline Max BUPA & 754.47 & 593.93 & 0.5 & 27.03 \\
\hline Religare & $1,091.61$ & 726.07 & 0.72 & 50.35 \\
\hline Star Health \& Allied Insurance & $4,145.00$ & $2,961.00$ & 2.75 & 39.99 \\
\hline Total & $8,296.43$ & $5,858.77$ & 5.5 & 41.61 \\
\hline
\end{tabular}


Standalone health insurers show premium growth of $41.61 \%$ as compared $16.95 \%$ of other non-life insurers excluding specialised insurers as shown in Table 3.

This is because of single-minded focus on health products only as they cannot rely on other products to meet overall targets. Further, the loss ratios for these companies in health were lower than other general insurers due to sound underwriting practices, innovative products, use of technology and lesser reliance on group health insurance.

To achieve the objective of increasing health Insurance penetration these standalone health insurance companies can tie up with one existing life insurance agent and one existing general insurance agent and use without going through the process of licensing them. This saves the time taken in appointment and licensing of agents. This is a privilege extended to them by IRDAI to increase penetration of health insurance in nook and corner of the country through agents. These companies have been able to expand their base of agents in short period of time.

Introduction of Portability: Pre October 2011 migration of policy from one insurer to another was not possible, one had to discontinue paying premium to one insurer and buying a fresh policy, further on discontinuing one insurer and buying a fresh policy, the benefits accumulated were lost like the waiting period for covering "Pre-existing Diseases". IRDA bought portability guidelines which ensure that new insurer shall allow for credit gained by the insured for pre-existing condition(s) in terms of waiting period". Customers can now change from one insurer to another without loss of accumulated benefits. This will also help in orderly growth of the sector.

\section{Challenges}

These lie in the nature of the product itself that is Insurance. It has been always difficult to market a product such as Health insurance, which essentially is not a physical product but a promise of service delivery at time of specific event or occurrence of disease. Insurance policy is a mere promise to pay the sum insured on happening of defined event giving rise to a claim. There is little customer pull for health insurance, which will come from awareness about the product and increase in savings and disposable income.

\section{High Loss Ratios}

Health insurance industry is plagued by high loss ratios especially in group health plans. Group health insurance (excluding govt. business) which had nearly $48 \%$ of the premium share in 2016-2017 had a loss ratio of $125 \%$ in comparison loss ratios of individual health/retail business loss ratios are much lower. There is dependence of group health insurance business to get bulk premium and lack of bargaining power in terms of pricing group health insurance due to stiff competition has affected the loss ratios. As is evident from the data below in Table 4 and Table 5.

Table 4: Figure 1: Health insurance premium - Class wise - (2013-17)

\begin{tabular}{|l|c|c|c|c|c|}
\hline Classification of Health Insurance Premium (excl. PA and Travel Business) & Rs Cr. \\
\hline Class of Business & $2012-13$ & $2013-14$ & $2014-15$ & $2015-16$ & $2016-17$ \\
\hline Government Sponsored Scheme including RSBY & 2348 & 2082 & 2474 & 2425 & 3090 \\
\hline & $15 \%$ & $12 \%$ & $12 \%$ & $10 \%$ & $10 \%$ \\
\hline Group Business (other than Government business) & 7186 & 8058 & 8899 & 11621 & 14718 \\
\hline & $47 \%$ & $46 \%$ & $44 \%$ & $48 \%$ & $48 \%$ \\
\hline Individual Business & 5919 & 7355 & 8772 & 10353 & 12584 \\
\hline Grand Total & $38 \%$ & $42 \%$ & $44 \%$ & $42 \%$ & $42 \%$ \\
\hline
\end{tabular}

Source: IRDAI Annual Report 2016-17

Table 5: Class wise health insurance -net incurred claims ratio - (2013-17)

\begin{tabular}{|l|c|c|c|c|c|}
\hline Class of business & $\mathbf{2 0 1 2 - 1 3}$ & $\mathbf{2 0 1 3 - 2 0 1 4}$ & $\mathbf{2 0 1 4 - 1 5}$ & $\mathbf{2 0 1 5 - 1 6}$ & $\mathbf{2 0 1 6 - 1 7}$ \\
\hline Government Sponsored Scheme including RSBY & $87 \%$ & $93 \%$ & $108 \%$ & $109 \%$ & $122 \%$ \\
\hline Group Business (other than Government business) & $104 \%$ & $110 \%$ & $116 \%$ & $120 \%$ & $125 \%$ \\
\hline Individual Business & $83 \%$ & $83 \%$ & $81 \%$ & $77 \%$ & $76 \%$ \\
\hline Total Business & $94 \%$ & $97 \%$ & $101 \%$ & $102 \%$ & $106 \%$ \\
\hline
\end{tabular}

Source: IRDAI Annual Report 2016-17

\section{Lack of Awareness}

Lack of awareness about health insurance products and insurance mechanism among people persists resulting in a disproportionate amount of time being invested in educating the potential customer with few gaps s remaining unaddressed until the time of claim.
Common perception among people that health insurance is not for the healthy and only those who are already sick need and tend to seek health cover.

\section{Attitude and Perceptions}

Indian consumer is price conscious and there is no immediate benefit, which accrues to him on buying health insurance. It is an expenditure for protection in 
future. People do not realize that insurance mainly provides protection against health risk and is not an investment, which will provide return. This is not difficult to comprehend as the customers first exposure was with buying life insurance products which were marketed as investment products. Very few people in India buy term insurance or pure life cover. This effects spills on to buying health insurance which is not able to distinguish between protection needs and investment products. Another issue is having the mind-set that only people with health problems need health insurance. This coupled with price consciousness of Indian consumers leads to buying inadequate cover or under insuring themselves even in case of taking the decision to purchase health insurance.

\section{Problem of Adverse Selection}

Adverse selection is the inclination of persons with below average health to apply for or continue insurance than people with average and above average health. This is more acute in individual than in group products. This leads to underwriting a substandard risk pool.

Premium increases become frequent and steeper leading to health insurance premiums becoming out of reach of wider healthy premium. Insurers generally assume adverse selection of 20 percent in India.

\section{Distribution and Marketing Issues}

There are many channels to market health Insurance. These have not made inroads in small towns and cities as insurers concentrate marketing efforts in metros. Looking at the data of health insurance sales by geographies, urban customers rule the roost. The cost of reaching tier 2 and tier 3 cities for insurers is high and lack of level of awareness about health insurance makes them stay away these geographies. There is inclination by the salesforce to go for the low hanging fruit and to meet stiff targets they try to solicit business from more aware urban customers.

\section{Lop Sided Portfolio Skewed towards Metros and few States}

According to the Insurance Regulatory Authority of India (IRDA) annual report for 2016-17, State-wise distribution of health insurance business has shown a much skewed distribution of health insurance business across various States \& Union territories. The cost of reaching tier 2 and tier 3 cities and lack of level of awareness about health insurance makes them stay away from these geographies. According to the Insurance Regulatory Authority of India (IRDA) annual report for 2016-17, while five states of Maharashtra, Tamil Nadu, Karnataka, Gujarat and Delhi contributed $70 \%$ of total health insurance premium in FY 2016-17, the rest 32 States/Union Territories accounted for only $30 \%$ of total premium collected by the industry. This impedes growth of the sector. Table 6 clearly brings out the same.

Table 6: Share of states in health insurance premium- (2016-17)

\begin{tabular}{|c|c|c|c|c|c|c|c|c|}
\hline \multicolumn{9}{|c|}{ Share of top 5 states in health insurance premium 2016-17 } \\
\hline \multirow[t]{3}{*}{ State/UT } & \multicolumn{2}{|c|}{$\begin{array}{l}\text { Group Business (other } \\
\text { than RSBY and Govt. } \\
\text { sponsored Schemes) }\end{array}$} & \multicolumn{2}{|c|}{$\begin{array}{c}\text { Govt. Business (RSBY } \\
\text { and Govt. sponsored } \\
\text { schemes) }\end{array}$} & \multicolumn{2}{|c|}{ Individual Business } & \multirow{2}{*}{$\begin{array}{l}\begin{array}{l}\text { Total H I } \\
\text { Business }\end{array} \\
\text { Amount in } \\
\end{array}$} & \multirow[b]{2}{*}{$\%$ in } \\
\hline & Amount in & $\%$ in & Amount in & $\%$ in & Amount in & $\%$ in & & \\
\hline & Rs. Lakhs & Premium & Rs. Lakhs & Premium & Rs. Lakhs & Premium & Rs. Lakhs & Premium \\
\hline Maharashtra & 559104 & 39 & 77311 & 25 & 331089 & 26 & 972378 & 32 \\
\hline Tamil Nadu & 221973 & 15 & 65723 & 21 & 98468 & 8 & 386165 & 13 \\
\hline Karnataka & 249490 & 17 & 8091 & 3 & 72322 & 6 & 329903 & 11 \\
\hline Delhi & 110356 & 7 & -4 & 0 & 128309 & 10 & 238661 & 8 \\
\hline Gujarat & 20524 & 1 & 5152 & 2 & 155696 & 12 & 181372 & 6 \\
\hline Rest of India & 310319 & 21 & 152774 & 49 & 472473 & 38 & 930692 & 30 \\
\hline Total & 1471766 & 100 & 309047 & 100 & 1258357 & 100 & 3039171 & 100 \\
\hline
\end{tabular}

Source: IRDA Annual Report 2016-17

\section{Unregulated Health Care Providers}

Insurance sector is regulated by IRDAI. Indian healthcare industry has no regulator to make it accountable to its citizens. No authority or regulator exists to bring accountability for hospitals, which are an important stakeholder in delivery of health care.

Indian population is choosing private hospitals over the public/government hospitals in a big way. Government hospitals are shunned due to long waiting time given for surgeries, lack of accommodation, lack of sanitation and apathetic treatment by its staff to patients. Public Hospital staff is overworked, underpaid, and unable to handle large inflow of patients to its doors. Government apathy in opening new public hospitals has worsened the situation further. The problem being more acute in rural India.

There are very few not for profit, charitable hospitals in Private sector. There has been huge investments in this space by private equity investors and corporates due to huge unmet demand for quality healthcare services.

Non standard billing or non standardised pricing leads to significant variations in pricing for similar ailments inflated bills, overcharging for treatments and diagnostic tests are other concern areas. These 
malpractices plague the hospitals, which are an important stakeholder in delivery of health care. This leads increase in claims ratio for Insurers.

\section{Conclusion}

The challenges are not unsurmountable and reflect on the need to increase the awareness levels for health insurance among Indians. With demographics in India's favour and low insurance penetration levels mean huge future growth potential. Recent increase in limit of foreign partners from $26 \%$ equity to $49 \%$ will be an incentive to invest in Indian Insurance sector. Health Insurance is an important instrument of social security for its citizens. Health Insurance portfolio of the industry has been the fastest growing segment and scope exists for further penetration and growth among the uncovered population in India.

\section{References}

1. http://pib.nic.in/newsite/PrintRelease.aspx?relid=115294

2. http://www.irda.gov.in Insurance Regulatory and Development Authority of India

3. http://www.iib.gov.in Insurance Information Bureau of India

4. http://www.thehealthsite.com/diseasesconditions/lifestyle-diseases-on-the-rise-in-urban-india/

5. Demographic Transition in India, Prof. PM Kulkarni. http://www.censusindia.gov.in/.../Year\%20end\%20semina r_11\%20dec.pdf
6. IRDA Journals

7. http://www.actuariesindia.org/downloads/gcadata/10thG CA/Emerging\%20Health\%20Insurance\%20in\%20IndiaAn\%20overview_J\%20Anitha.pdf

8. Sengupta A, Nundy S. The private health sector in India: Is burgeoning, but at the cost of public health care. $B M J$ : British Medical Journal. 2005;331(7526):1157-1158.

9. India Flags Low Health Insurance Penetration as Damper to Growth. (2018). Retrieved from https://www.insurancejournal.com/news/international/201 8/02/06/479711.htm

10. Things to know about India's Healthcare System | Forbes India Blog. (2018). Retrieved from http://www.forbesindia.com/blog/health/5-things-toknow-about-the-indias-healthcare-system/

11. Rao, K. (2018). Health Insurance Goes Digital. Retrieved from http://businessworld.in/article/Health-InsuranceGoes-Digital/17-01-2017-111579/

12. The health insurance frontier in India. (2018). Retrieved from

http://institute.swissre.com/research/overview/expertise_p ublication/The_health_insurance_frontier_in_India.html

13. In India, Health Insurance Does not Work in a Desirable or Sustainable Manner. (2018). Retrieved from https://thewire.in/health/india-health-insurance-industry

14. India, \& Analysis, I. (2018). Insurance Sector in India: Industry Overview, Market Size \& Trends | IBEF. Retrieved from https://www.ibef.org/industry/insurancesector-india.aspx 